\title{
Sources of growth of bovine meat exports from Mato Grosso from 1996 to 2010
}

\author{
Josiane de Oliveira ${ }^{1}$, Regina Célia de Carvalho", Márcia Batista da Fonseca ${ }^{2}$, Sandra Cristina \\ de Moura Bonjour ${ }^{1}$
}

\footnotetext{
1 Universidade Federal de Mato Grosso - UFMT.

2 Universidade Federal da Paraíba - UFPB.
}

\begin{abstract}
The objective of this study is to analyze the competiveness of the Mato Grosso bovine meat in view of the international market through researching the factors that most influenced the performance of the Mato Grosso bovine meat exports from 1996 to 2010. Specifically, the aim was to verify if the Mato Grosso bovine meat contains competitive sustainable advantages to maintain its international market position and if it is possible to increase its market share. To do so, a comparison of the competitiveness of bovine meat export of Mato Grosso was performed. Also, the competitiveness of the Brazilian meat exports was compared with that of other main exporters of this product, namely, Australia, Argentina and the United States through the use of the Constant Market Share Model (CMS). The obtained results of CMS with respect to Mato Grosso made it possible to verify that competitiveness was not a dominant factor throughout the whole period and that Mato Grosso will be able to maintain its position in the world market and expand its market share further. These results are caused by the destination of the exports and the increase of global trade rather than competitiveness.
\end{abstract}

Key Words: agribusiness, constant market share, global trade

\section{Introduction}

Brazil has the largest commercial bovine herd of the world and since 2003 it has become the largest exporter (in quantity) of beef meat worldwide. The country has sold fresh meat to 107 countries, and the main consumer markets are the Middle East (43\%), Russia (30\%) and the European Union (5\%) (SECEX, 2011).

Maury \& Andrade (2007) state that due to pressures exerted by globalization and consequent increase in competitiveness the Brazilian cattle farming had an increase in efficient productivity in order to provide better quality products for the consumer market.

The State of Mato Grosso is one of the most important in Brazil as it appears in the national scenario with the largest cattle herd since 2003. In the same year, it assumed the second position as beef meat exporter with the largest number of slaughtered heads.

The exports from Mato Grosso have increased considerably, from 66,308 equivalent carcass tons in 2003 to 339,613 equivalent carcass tons in 2010, which represented $512 \%$ of the growth (SECEX, 2011). This increase has benefited all links in the beef chain. The importance of this study is thus related to the competitiveness needed for a growing and continuous performance, so that the state does not lose its market and that the sector does not have a disruption in its economy.

With respect to this, this study was conducted to determine if the Mato Grosso bovine meat contains competitive sustainable advantages to maintain its international market position. To do so, this study takes on the hypothesis that Mato Grosso succeeded to increase its market share in the international market due to the fact that this state obtained competitiveness gains, which allowed for the expansion of exports.

Thus, the objective of this study is to analyze, through the Constant-Market-Share (CMS) Model, the competitiveness of the Mato Grosso bovine meat in view of the international market, through researching the factors that most influenced the performance of the Mato Grosso bovine meat exports from 1996 to 2010. Specifically, it aims to verify if the Mato Grosso bovine meat contains competitive sustainable advantages to maintain its international market position and if it is possible to increase its market share.

\section{Material and Methods}

The performance of the exports of a country, according to Guimarães \& Campos (2006), is one of the ways to verify the competitiveness of a product; if they are competitive, 
they enlarge their participation in the world trade. This is a concept that comprises not only the production conditions, but also all other factors that inhibit or stimulate exports.

For the development of this study, the concept of competitiveness resulting from the CMS Model was chosen. According to Machado (2005) the CMS model allows for the determination of factors that influenced the export performance of a country over the years.

According to Leamer \& Stern (1970), the presupposed base of this model is that the participation of a country or trade block in the international market remains constant and if there is any alternation, such as an increase in exportations, it is due to competitiveness.

The specific formulation of the CMS model considers as basic variable the value of the exports.

The model is given by:

$$
V^{*}-V \equiv r V+\sum_{i}\left(\mathrm{r}_{\mathrm{i}}-\mathrm{r}\right) V_{i}+\sum_{i} \sum_{j}\left(r_{i j}-r_{i}\right) V_{i j}+\sum_{i} \sum_{j}\left(V_{i j}^{*}+V_{i j}-r_{i j} V_{i j}\right)
$$
(a)
(b)
(c)
(d)

Where: $V=$ total value of the exports of country $\mathrm{Z}$, period $1 ; V^{*}=$ total value of the exports of country $\mathrm{Z}$, period 2; $r=$ increase of global exports from period 1 to period 2; $r_{i}=$ increase of the global exports of product $\mathrm{i}$ from period 1 to period $2 ; V_{i j}=$ total value of exports of product i from country $\mathrm{Z}$ to country $\mathrm{j}$, period $1 ; V_{i j}^{*}=$ total value of exports of product $i$ from country $Z$ to country $j$, period 2; $r_{i j}=$ percentage increase of the global exports of product I of country $\mathrm{j}$ from period 1 to period 2 .

According to equation (1), the variations in participation of exports of a certain country in the global trade are divided into four effects:

a) Growth effect in global trade: reflects the growth observed by exports of the country or block in relation to the same growth rate of the world trade, that is, the export growth occurs due to the worldwide export growth.

b) Composition effect of the agenda: indicates that if the global exports of the product increase more than the world average for all the exported goods, its results will be positive, and that the composition effect of the export agenda of country A are concentrated on the product of highest expansion or when the growth rate is superior to that of the world average. If the effect is negative, it indicates that the exports of country A are concentrated in markets with low growth.

c) Destination effect of exports: represents the gains and losses of the growth percentage due to the fact that the country exports to markets that grew at higher or lower rates than those of other countries, that is, the destination effect of exports will be positive if country A has concentrated its exports in markets that experienced more dynamism in the analyzed period and negative if they are concentrated in more stagnating regions.

d) Residual effect, representing competitiveness: indicates the growth percentage of gains or losses of product participation in different markets due to gains or losses of competitiveness, whether they are in terms of prices and/ or costs, or due to the improvement in the quality of the product and/or conditions of investment.

According to Carvalho et al. (2004), besides being influenced by the relative prices, the competitive effect is also influenced by other factors such as technological changes; incentive measures; marketing actions; improvement of the mechanisms of financing and credit; and good service delivery.

For Carvalho (1995), however, although this model has a retrospective feature, it is possible to use it to make inferences on the direction of the export sector to more favorable markets, under the assumption of a continuity in the markets trends observed.

In order to reach the proposed aim, data on the global exports of bovine meat from 1996 to 2010, of Brazil (Mato Grosso), Argentina, Australia and the United States were collected. These countries were chosen because they were the biggest global exporters of bovine meat in the period of analysis. It must also be highlighted that India, despite being important in the international market for representing one of the largest global exporters of bovine meat was excluded from the analysis because its data were incomplete on the database used, the United Nations (COMTRADE), mainly in the initial period of the study.

Besides the global data, based on the products identified through the codes of the Common Nomenclature of Mercosul (NCM), the products described in Section I, Chapter 2 were considered, surveying the data relative to codes 1602.50 .00 to 0210.20 .00 and the intervals designated in: 0201.10 .00 to $0201.30 .00 ; 0202.10 .00$ to 0202.30 .00 ; and 02061000 to 0206.29.90. The selection of these codes occurred because they were common to all the countries and to the state of Mato Grosso, not to mention they represented $95.84 \%$ of Mato Grosso exports of bovine meat and $95.18 \%$ of the Brazilian exports of bovine meat in 2010.

The data of the exports of bovine meat from Mato Grosso and Brazil were collected from the Alice Web System, available through the site of the Ministry of Development, Industry and Foreign Trade (MDIC). The data of bovine meat exports from Australia, Argentina, United States and the rest of the world were obtained at COMTRADE (2011).

This study will not discuss the composition effect on exports, since it is about the analysis of a single segment of 
the beef productive chain. According to Machado (2005), the use of the CMS method to a single product nulls the composition effect in such a way that the part of the equation relative to this effect was eliminated.

According to Diz (2008), Coronel (2008) and Machado (2005), the CMS model was used as a way of understanding the factors that determine the growth of the exports. The values of exports used were the simple average of the periods, taking into account that the use of this resource is necessary to prevent the results obtained from being subjected to drastic annual variations from one period to another.

For Carvalho (1995), the application of the CMS model is carried out between discrete points in time. Therefore, it is necessary that the periods of analyses be established. A division in shorter periods allows for more accurately identifying the changes that occurred in the export structure, between the beginning and the end of the study period.

The CMS calculation for the years from 1996 to 2010 four sub periods were taken into account: the first period comprises the years from 1996 to 1999; the second period from 2000 to 2003; the third period from 2004 to 2007; and the fourth period from 2008 to 2010 . This division was made so as to minimize the possible impacts suffered by meat exports during the period. These sub periods were selected so as to represent some important moments for the Brazilian and international economy that have somehow influenced the bovine meat exports, as follows:

a) Period I - 1996 to 1999: represents the period in which a fixed exchange rate policy was in force, since the implantation of the 'Brazilian Real' monetary plan in 1994 was a period marked by a decrease in exports and increase of the imports in a fast and solid way. However, in January 1999 a period of currency devaluation with the adoption of the floating exchange rate regime by the Brazilian government started.

b) Period II - 2000 to 2003: represents the period of financial leverage of the Brazilian agro-industrial exports; the bovine herds from the United States and Argentina faced sanitary problems; a serious drought problem in Australia; Brazil became the biggest global export of bovine meat in 2003.

c) Period III - 2004 to 2007: a period in which there was a considerable increase of the exports of Brazilian bovine meat due to the reduction of the American offer. However, in 2007 the Brazilian meat suffered embargos both in Russia and in the European Union, two of the biggest consumer markets of Brazilian meat.

d) Period IV - 2008 to 2010: a period which refers to the more recent years of consolidation of Brazilian bovine meat exports, but also marked by the international economic crisis that affected mainly North America.

For the data analysis in this research, the software Excel $^{\circledR}$ was used. The analyses were carried out from the second period in relation to the first, from the third period in relation to the second and from the fourth in relation to the third, for each one of the aforementioned countries and for Mato Grosso.

\section{Results and Discussion}

When analyzing the growth sources in the export of bovine meat from Mato Grosso, it is observed that in period II (2000 - 2003), in relation to I (1999 - 2000), the effect that contributed the most for the export growth was competitiveness (Table 1), with $1041 \%$. The same effect was also found in the work of Souza (2008) in relation to the increase of exports of soybean meals to Iran.

The global trade growth effect was significantly negative (-1141\%), indicating that Mato Grosso beef exports did not grow at the same rate as the global trade, that is, Mato Grosso exports grew $8.71 \%$ and the global exports increased $10.56 \%$ for the same period. These results differed from Souza (2008), for cotton, where the most important growth effect was the global trade.

Another effect that contributed positively for the increase in exports in this period was the export destination, whose result was fairly relevant (200\%), indicating that Mato Grosso concentrated its exports in markets that were more dynamic in the period analyzed, that is, which grew at higher rates than the average observed for other countries.

In relation to II (2000 - 2003), period III (2004 - 2007) had a similar behavior to IV (2008 - 2010) in relation to III (2004 - 2007), that is, both had a negative competitive effect and the effect that contributed the most for the growth of export was the export destination.

Despite the growth effect of global trade not being the fact that most contributed to the increase of exports, it can be observed that it has been gradually evolving over the periods, i.e., comparing periods II-I (-1141\%), III-II (24\%) and IV-III (44\%), observing that the exports of bovine meat in Mato Grosso have followed the global exports as can

Table 1 - Sources of growth in exports of Mato Grosso beef (1996 - 2010)

\begin{tabular}{lccc}
\hline Effects & Period II-I & Period III-II & Period IV-III \\
\hline Growth of global trade & $-1141 \%$ & $24 \%$ & $44 \%$ \\
Export destination & $200 \%$ & $80 \%$ & $81 \%$ \\
Competitiveness & $1041 \%$ & $-4 \%$ & $-25 \%$ \\
Total & $100 \%$ & $100 \%$ & $100 \%$ \\
\hline
\end{tabular}

Source: Research data. 
be seen in period III in relation to II, the growth rate of exports was of $418.21 \%$, while the global was of $97.36 \%$. In period III in relation to II the growth rate of exports in Mato Grosso was $67.93 \%$ and the global was $23.82 \%$.

The results of the CMS obtained for Brazil (Table 2) showed that both the destination effect of exports and the growth of global trade were strong enough to overcome the negative participation of the competitiveness effect. However, the results of the study of Coronel (2008) indicated that this was the main responsible effect for the increase in the Brazilian exports of soybean, soybean meals and soybean oil from 1995 to 1998 in relation to the period from 1999 to 2001.

When analyzing the evolution of the effects, it is observed that an inversion of the participation effect occurs, that is, the destination effect of export gives way to the growth effect of the global trade, showing that Brazil was able to increase its sales as the world export increased.

As the growth in the global trade was the factor that contributed the most to the increase in exports of Brazilian bovine meat in period IV in relation to III, the same occurred with the behavior of the exports of soybean, soybean meal and soybean oil for the period from 1999 to 2001 compared with the period from 2002 to 2004 found by Coronel (2008).

With the discovery of cases of Bovine Spongiform Encephalopathy (BSE), better known as "mad cow disease" in England in 2001, the markets that until then were supplied by England and other European countries became available for the Brazilian bovine meat market.

In 2006 and 2007, the European Union was the main importer market of Brazilian bovine meat. In 2001, due to an epidemic of foot-and-mouth disease in Argentina, Chile stopped buying meat from that country and started to buy Brazilian meat.

In 2002, climatic problems considerably reduced the size of American and Australian herds, directly affecting the production of these countries. Also, in 2003 several countries suspended the imports of bovine meat from the United States due to the detection of the "mad cow disease" in its animals, giving Brazil a chance in new markets.

Table 2 - Sources of growth in exports of Brazilian bovine meat (1996 - 2010)

\begin{tabular}{lccc}
\hline Effects & Period II-I & Period III-II & Period IV-III \\
\hline Growth of global trade & $11 \%$ & $55 \%$ & $178 \%$ \\
Export destination & $94 \%$ & $63 \%$ & $56 \%$ \\
Competitiveness & $-5 \%$ & $-17 \%$ & $-134 \%$ \\
Total & $100 \%$ & $100 \%$ & $100 \%$ \\
\hline Source
\end{tabular}

Source: Research data.
Brazil invested in vaccination programs that almost eliminated the risk of foot-and-mouth disease in its herd, an important measure for export, in addition to being one of the countries that invests most in genetics. The average age of slaughter fell from 4 to 3 years, increasing productivity, allowing to slaughter young steer at two years. The cattle slaughter industry invested in special cuts that also added value to the meat.

Factors such as these were responsible for significantly increasing the markets served by Brazilian exports of bovine meat, in such a way that in 1999 there were over 40 countries and in 2010, the fresh meat was exported to over 107 countries and the industrialized meat to 125 countries, and internal organs to 85 countries, making it possible for the Brazilian meat to be commercialized in markets such as Russia, the Middle East, the European Union, the United Kingdom and Hong Kong among others used to higher quality beef.

Analyzing the results of CMS of the United States (Table 3), it can be observed that in period II (2000 - 2003) in relation to I (1996 - 1999), the growth effects of the global trade and export destination were the main responsible for the growth of North American export in these periods. However the competitiveness effect was negative. It can be inferred that the negative influence of this effect indicates that this market was not able to increase its exports to new markets to compensate the loss of its main importers.

According to Machado (2005), the participation of the United States in the Canadian imports went from 52.44\% to $31.81 \%$, the Mexican from $66.83 \%$ to $52.16 \%$ and the Japanese from $52.27 \%$ to $50.63 \%$ in period I in relation to period II.

In period III (2004 - 2007) in relation to period II (2000 - 2003) the growth effect of the global trade contributed negatively, that is, the United States could not increase its exports of bovine meat while the global exports grew. The destination effects of exports and competitiveness were those which contributed the most for the growth of the bovine export, with emphasis on the latter.

In December 2003, after the notification of one case of BSE in the state of Washington, more than 70 countries

Table 3 - Sources of growth in exports of American bovine meat (1996 - 2010)

\begin{tabular}{lccc}
\hline Effects & Period II-I & Period III-II & Period IV-III \\
\hline Growth of global trade & $260 \%$ & $-34 \%$ & $20 \%$ \\
Export destination & $67 \%$ & $54 \%$ & $88 \%$ \\
Competitiveness & $-227 \%$ & $80 \%$ & $-8 \%$ \\
Total & $100 \%$ & $100 \%$ & $100 \%$ \\
\hline
\end{tabular}

Source: Research data. 
suspended their imports of bovine meat from the United States, including their biggest import market, Japan. The Japanese government alleviated the embargo in late 2005. With these embargos, the international bovine meat market had to be rearranged, since the bovine meat demand was not reduced.

The results of period IV - III reveal that the export growth had a small negative influence of the competitiveness effect (8\%); however, it was compensated with the growth effects of the global trade and export destination. Such result shows that in this period the United States were in a recovering phase of its bovine meat export, once again gaining the trust of their importers.

Concerning the Australian exports of bovine meat (Table 4), in period II (2000 - 2003) in relation to I (1996 - 1999) the effect that most contributed to the export increase was the competitiveness effect; the destination effect of exports also influenced positively. However, the exports could have been higher if it were not for the growth effect of the global trade that was negative, indicating that the growth rate of the Australian exports was lower than the global one for the period. In 2002, an intense dry period in several regions of Australia started; a fact that considerably impaired the production and consequently the exports.

Period III (2004 - 2007) in relation to period II (2000 - 2003) reflects a situation in which only the growth effect of the global trade had a positive influence on the export growth of Australian bovine meat. This result is similar to that found by Machado (2005), which can be explained in part by the fact that, in this period, Australia continued facing problems with drought. Besides this, the high costs of production and the valorization of the Australian currency reduced the competitiveness of the exports.

In relation to period III (2004 - 2007) in terms of growth effects of exports, period IV (2008 - 2010) was similar to period II in relation to period I, that is, the growth effect of global trade had a negative influence on the Australian exports and once more, the growth rate of global exports of bovine meat (24\%) were higher than the Australian (6.2\%).

The results show that, for Argentina (Table 5), period II (2000 - 2003) in relation to period I (1996 - 1999), the

Table 4 - Sources of growth in exports of Australian bovine meat (1996 - 2010)

\begin{tabular}{lccc}
\hline Effects & Period II-I & Period III-II & Period IV-III \\
\hline Growth of global trade & $-1693 \%$ & $252 \%$ & $-148 \%$ \\
Export destination & $253 \%$ & $-20 \%$ & $109 \%$ \\
Competitiveness & $1540 \%$ & $-132 \%$ & $139 \%$ \\
Total & $100 \%$ & $100 \%$ & $100 \%$ \\
\hline
\end{tabular}

Source: Research data. result of the growth effect of the global trade was negative, and the exports were not worse due to the competitiveness effects and especially the export destination. In period II, more specifically in 2001, an epidemic of foot-andmouth disease occurred in the country, causing many of its markets to stop buying Argentinean meat and searching for new markets. In this period the growth rate of global exports of bovine meat was $11 \%$; however, in Argentina it was negative, $38 \%$.

Period III (2004 - 2007) presented a difference in relation to period II (2000 - 2003), considering that the growth of the global trade was the most responsible for influencing the export growth. Another positive factor was the export destination, indicating that the exports searched markets that had more dynamic growth, in addition to the fact that in this period the growth rate of the exports of Argentinean bovine meat exceeded the global exports in $60 \%$.

Despite this improvement in the performance of the Argentinean bovine meat exports, the competitiveness effect was a factor that influenced negatively in this period. Similar result was found by Machado (2005), which can be explained by political interference in the sector given by the high cost of the Argentinean meat in the international market and the increase in the demand for Argentinean bovine meat. Considering the discovery of an outbreak of foot-and-mouth disease in Brazil (the state of Pará) and of the Avian influenza in Europe, there was a preference by the producers for exporting instead of supplying the internal market, which generated an increase in the internal prices of meat, causing two main consequences: inflation and difficulty for the population to acquire this product.

Because of this, after beating the record in the bovine meat exports in 2005, in March of 2006 the Argentinean government forbade the bovine meat exports for a period of 180 days. With this measure, the intention of the government was to increase its share in the domestic market and force a drop in the price, which generated a strong reaction in the Argentinean bovine meat chain.

The pressures exerted by the producers were so great that in June 2006 the Argentinean government allowed the export of $40 \%$ of the products in the second semester of 2005 , with the aim of resuming its sales overseas. However,

Table 5 - Sources of growth in exports of Argentinean bovine meat $(1996$ - 2010)

\begin{tabular}{lccc}
\hline Effects & Period II-I & Period III-II & Period IV-III \\
\hline Growth of global trade & $-19 \%$ & $81 \%$ & $401 \%$ \\
Export destination & $87 \%$ & $50 \%$ & $17 \%$ \\
Competitiveness & $32 \%$ & $-31 \%$ & $-318 \%$ \\
Total & $100 \%$ & $100 \%$ & $100 \%$ \\
\hline Source: Research data. & & &
\end{tabular}


many producers, feeling discouraged, reduced their investments. Also, from 2005 to 2007, about 3.5 million hectares of grazing areas were replaced by soybean. All this affected the production directly, and consequently the competitiveness of the exports of Argentinean bovine meat, since it generated insecurity in the international market for not having the guarantee of the product.

The sources of growth in exports of Argentinean bovine meat in period IV (2008 - 2010) in relation to period III (2004 - 2007) were similar to period III (2004). In relation to period II (2000 - 2003) the growth effects of the global trade and the export destination were those that most influenced the export growth.

The competitiveness effect remained negative and the insecurity of the market in relation to the Argentinean meat trade continued, even when the government released the exports in late 2006 and once more interfered in this sector by imposing barriers on the bovine meat exports in April 2007 by establishing a maximum level for export and demanding that the rural entities sign an agreement that would guarantee the domestic supply with reasonable prices, besides controlling the price of the 13 most consumed types of meat by the Argentinean population.

\section{Conclusions}

From 2003 onward there was a repositioning in the international bovine meat market. Brazil has become the main exporting country in the world concerning this product, with considerable contributions from the state of Mato Grosso. This is due to the fact that this state has the largest bovine meat herd, the largest amount of slaughter houses and is the second bovine meat exporter state of Brazil. The positive national performance in the bovine meat segment, with respect to produced volume, and the conquest of new markets are a reflection of the advances in productivity indices. This is a result of improvements regarding nutrition, genetics and sanitary conditions. Thus, it is possible to confirm that the state of Mato Grosso has evolved in a promising way in this market, with an increase in herds, slaughter houses, production and, consequently, exports, which proves the importance of the sector to the economy of this state. However, the hypothesis of this study has been partially rejected, since the competitiveness factor was not dominant in the analyzed period. Mato Grosso has maintained its position concerning the world market and increased its market share due to the export destination and the increase in the international exports rather than competitiveness.

\section{References}

ALICE-WEB. Sistema de análise das informações de comércio exteriorviainternet.Available at: $<\mathrm{http} / / /$ aliceweb.desenvolvimento. gov.br/consulta_nova/consulta.asp?tip_consulta=ExpExp\&titulo $\mathrm{p}=$ Exportação\%20Brasileira\&titulo_s=1996\%20a\%202011>. Accessed on: Jul. 23, 2011

CARVALHO, F.M.A. Comportamento das exportações brasileiras e a dinâmica do complexo agroindustrial. 1995. 126f. Tese (Doutorado em Economia) - Escola Superior de Agricultura "Luiz de Queiroz', Piracicaba.

CARVALHO, M.A; SILVA, C.; NEGRI NETO, A. Exportações brasileiras de produtos agrícolas e mudanças na demanda mundial de alimentos. Economia e Sociedade, v.13, n.2 (23), p.133-145, 2004.

COMTRADE. United Nations Commodity Trade Statistics Database. Available at: $<$ http://comtrade.un.org/db/mr/rfCommoditiesList.aspx $>$. Accessed on: Jul. 8, 2011.

CORONEL, D.A. Fontes de crescimento e orientação regional das exportações brasileiras do complexo da soja. 2008. 114f. Dissertação (Mestrado em Agronegócios) - Universidade Federal do Rio Grande do Sul, Porto Alegre.

DIZ, L.A.C. Competitividade internacional das exportações brasileiras de manga e uva. 2008. 95f. Dissertação (Mestrado em Economia Aplicada) - Escola Superior de Agricultura "Luiz de Queiroz", Piracicaba.

GUIMARÃES, D.D.; CAMPOS, A.C. Competitividade das exportações brasileiras de milho: 1990/2004. In: XLIV CONGRESSO DA SOCIEDADE BRASILEIRA DE ECONOMIA, ADMINISTRAÇÃO E SOCIOLOGIA RURAL - SOBER, 2006, Fortaleza. Anais... Fortaleza, 2006. Available at: <http://www. sober.org.br/palestra/5/548.pdf > Acessed on Oct. 5, 2010.

LEAMER, E.E.; STERN, R.M. Quantitative internacional economics. Boston, Massachusetts: Allyn and Bacon, 1970. 209p.

MACHADO, L.V.N. A posição competitiva do Brasil no mercado internacional de carne bovina: uma aplicação do método Constant-Market-Share， 1995-2003. 2005. 111f. Dissertação (Mestrado em Economia) - Universidade da Amazônia, Belém.

MAURY, P.M.; ANDRADE, L.A. A diferenciação pela qualidade. In: MILAN, M.; ZEN, S.; MIRANDA, S.H.G. et al. (Org.) Sistema de qualidade nas cadeias agroindustriais. São Paulo: [s.n.], 2007. p.119-139.

SECRETARIA DE COMÉRCIO EXTERIOR - SECEX. Estatística de comércio exterior. Balança comercial: Unidades da Federação. Available at: <http://www.desenvolvimento.gov.br/sitio/interna/ interna.php?area $=5 \&$ menu=1076 $>$. Accessed on: May 6, 2011 .

SOUZA, S.S.S. Análise da competitividade do algodão e da soja de Mato Grosso no período de 1990 a 2006. 104f. 2008. Dissertação (Mestrado em Agronegócios e Desenvolvimento Regional) Universidade Federal de Mato Grosso, Mato Grosso. 